the company by his predecessor, and likewise of the Fresh water canal constructed in connection with the work, the company reserving the right to use it. For these also he was to pay an indemnity.

The opening of the canal took place on November 17, 1869. It was a complete triumph for its builder. De Lesseps was loaded with honors, and attained the pinnacle of ambition for a Frenchman-he was elected to the French Academy. Throughout France he was hailed as a great engineer and a great patriot.

Few men, indeed, have enjoyed the fruits of their achievements as satisfactorily as did de Lesseps, for a time. But the end of his life was destined to be overshadowed by tragedy, in the form of his disastrous attempt to build the Panama Canal by the same methods as he used at the Isthmus of Suez. And therein lies, in great measure, the reason for his failure. In the latter case, the natural obstacles to be overcome presented no overwhelming problems, whereas at Panama the appalling sanitary conditions and the treacherous formation at the site of the Culebra Cut were not to be vanquished by diplomacy or enthusiasm. It is probable that if de Lesseps had had the youth and health to superintend personally the work at the American canal as he did at the Egyptian one, the attempt would not have ended in a financial scandal. But gifted as he was, he lacked the unemotional scientific patience with which Goethals attacked his problem. And whether or not, even in the prime of life, he would have brought the Panama enterprise to a successful conclusion is a matter for doubt.

\title{
A White Oak Plaque of the Flying Cloud made by a Steamship Officer
}

$A_{N}$ officer of the Society has presented the organization with an unusual gift, a white oak bas-relief of the famous clipper ship Flying Cloud. It was brought into the office of the Boston Globe by the artist, Robert Blight, chief officer of the steamship Maryland, and thence came to the Society. The plaque, done from two or three prints and an oil painting, is considered one of the finest examples of marine carving. Mr. Blight is a genuine deep-sea sailor, who has spent forty-one of his fifty-six years in ships. For twelve 


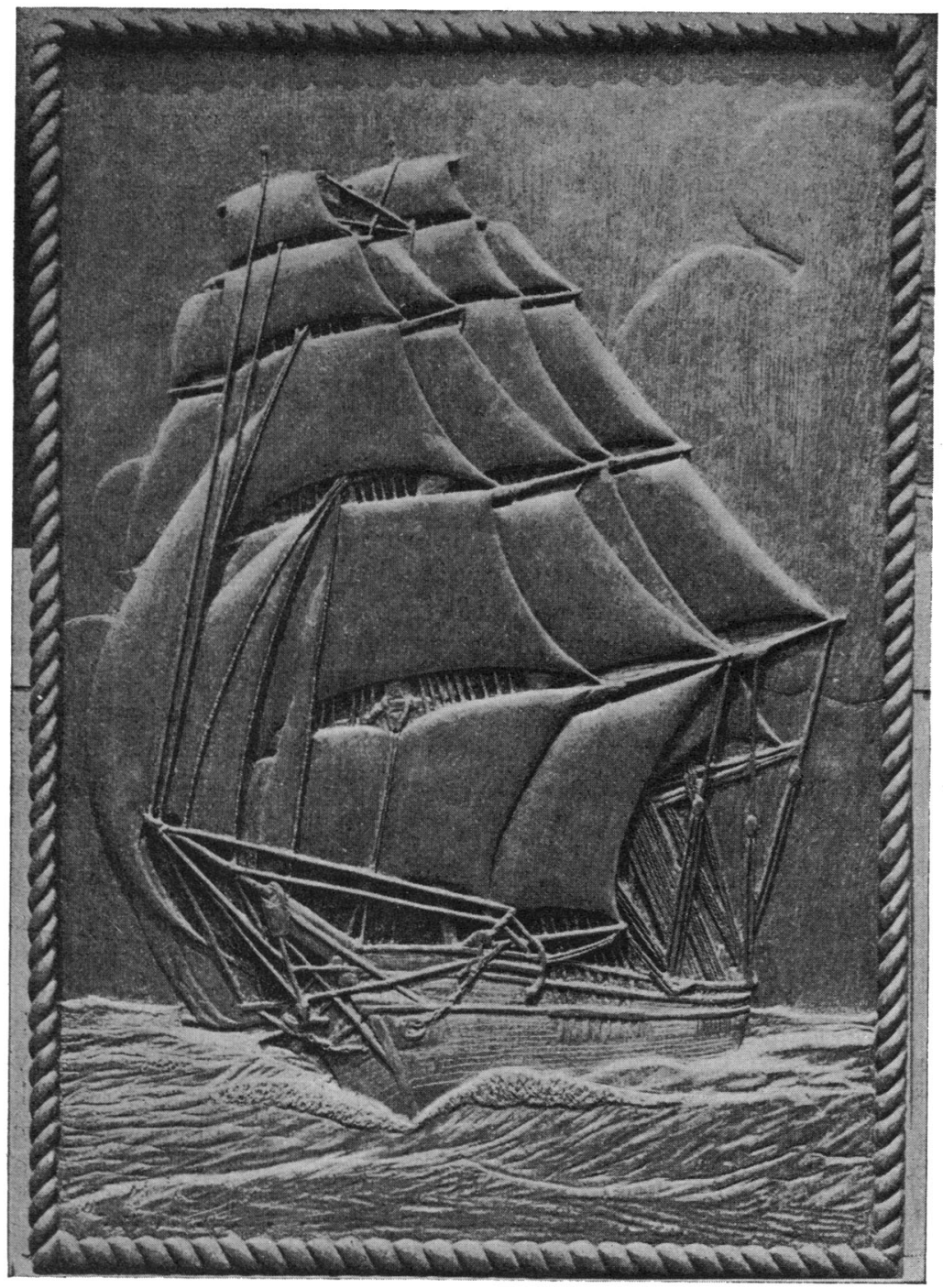

A Photograph of the Plaque of the Clipper Flying Cloud, MADE By Mr. Blight 
years he sailed in sailing vessels, but for the last three decades he has been in steam.

An account in the Globe of the carving describes the ship as running before the wind on her port quarter, her hull heeled over just a trifle. "She has all sails set, including both royal and t'gallant stun'sails, and there is life and beauty in the picture. One can almost hear the crackling and booming of the canvas."

"The making of the bas-relief," continues the Globe writer, "required between 300 and 400 hours of Mr. Blight's leisure time, and the utilization of a kit of perhaps twenty different tools. This is no dory carved out with a jacknife - it is a thorough work of art.

"A sign of its perfection lies in the 'undercutting.' 'That is, to give life to rigging, the sculptor cut away the wood beneath the cordage so that part of the rigging stands out in full relief. This undercutting lightens the whole composition.

"The ship is about two feet tall, from water line to truck. The whole plaque is about twenty-nine inches tall by twenty-two inches wide. Its border is carved in three quarter relief into the semblance of rope. In its thickest part the plaque is something less than two inches through.

"The carving of the thing required a vast amount of care. One difficulty was the impossibility of working on it in hot weather. The least dampness of perspiration, Blight says, will stain white oak and spoil its appearance. As a result, he had to work on it only in cool weather.

"A thick coating of oil was applied to it when it was finished, so that it is now almost the color of a coffee berry. The oil will keep the wood from becoming discolored and at the same time will strengthen the natural resistance of the oak to decay.

"Mr. Blight is an Englishman. His home is in a little town in Sussex, where he lives in a cottage almost five centuries old. Carving and painting are his twin hobbies. Ships he carves from oak, flowers from maple. The latter wood, he says, has almost no grain, and can be more easily worked into the intricate likenesses of flowers. ...

"During the World War he made numerous trips through the war zone. Once he was torpedoed. His speech reflects the life he has led and the reading he has done on shipboard. His broad Sussex accent trails off occasionally into an entirely American drawl, and he has the gift of making friends." 